Article

\title{
Optimization of Reducing Sugar Production from Manihot glaziovii Starch Using Response Surface Methodology
}

\author{
Abdi Hanra Sebayang 1,2, Masjuki Haji Hassan ${ }^{1}$, Hwai Chyuan Ong 1,*, Surya Dharma ${ }^{1,2}$, \\ Arridina Susan Silitonga ${ }^{1,2}$, Fitranto Kusumo ${ }^{1}$, Teuku Meurah Indra Mahlia ${ }^{3}$ and \\ Aditiya Harjon Bahar ${ }^{4}$ \\ 1 Department of Mechanical Engineering, Faculty of Engineering, University of Malaya, Kuala Lumpur 50603, \\ Malaysia; abdisebayang@yahoo.co.id (A.H.S.); masjuk@um.edu.my (M.H.H.); sury4_m3@yahoo.com (S.D.); \\ ardinsu@yahoo.co.id (A.S.S.); fitrantokusumo@yahoo.co.id (F.K.) \\ 2 Department of Mechanical Engineering, Medan State Polytechnic, Medan 20155, Indonesia \\ 3 Department of Mechanical Engineering, Universiti Tenaga Nasional, Kajang 43000, Selangor, Malaysia; \\ tmi.mahlia@gmail.com \\ 4 Department of Mechanical Engineering, Faculty of Engineering, The University of Melbourne, Parkville, \\ VIC 3010, Australia; aditharjon@gmail.com \\ * Correspondence: onghc@um.edu.my or ong1983@yahoo.com; Tel.: +60-16-590-3110; Fax: +60-37-967-5317
}

Academic Editor: Thomas E. Amidon

Received: 14 June 2016; Accepted: 4 September 2016; Published: 1 January 2017

\begin{abstract}
Bioethanol is known as a viable alternative fuel to solve both energy and environmental crises. This study used response surface methodology based on the Box-Behnken experimental design to obtain the optimum conditions for and quality of bioethanol production. Enzymatic hydrolysis optimization was performed with selected hydrolysis parameters, including substrate loading, stroke speed, $\alpha$-amylase concentration and amyloglucosidase concentration. From the experiment, the resulting optimum conditions are $23.88 \%(w / v)$ substrate loading, $109.43 \mathrm{U} / \mathrm{g} \alpha$-amylase concentration, $65.44 \mathrm{U} / \mathrm{mL}$ amyloglucosidase concentration and $74.87 \mathrm{rpm}$ stroke speed, which yielded $196.23 \mathrm{~g} / \mathrm{L}$ reducing sugar. The fermentation process was also carried out, with a production value of $0.45 \mathrm{~g}$ ethanol/g reducing sugar, which is equivalent to $88.61 \%$ of ethanol yield after fermentation by using Saccharomyces cerevisiae (S. cerevisiae). The physical and chemical properties of the produced ethanol are within the specifications of the ASTM D4806 standard. The good quality of ethanol produced from this study indicates that Manihot glaziovii (M. glaziovii) has great potential as bioethanol feedstock.
\end{abstract}

Keywords: Manihot glaziovii (M. glaziovii); optimization; hydrolysis; fermentation; bioethanol; alternative fuel

\section{Introduction}

The use of alternative fuels has rapidly developed with the objective of reducing the impact of continuously burning non-renewable fossil fuel. Currently, the predominant bioethanol is generally used blended with gasoline to push down the usage of conventional fuel and can be used in existing motor engines [1]. Bioethanol is a liquid resulting from fermentation of sugar and it is sourced from plants containing carbohydrates (starch) [2]. Moreover, microorganisms are used as enzymes in the fermentation process [3]. Bioethanol is widely used as a biofuel due to the following reasons: (1) bioethanol has high oxygen content and octane number; (2) bioethanol is non-toxic; and (3) bioethanol is environmentally friendly since it decreases pollutant emissions such as carbon monoxide, sulphur and nitrogen oxides $[4,5]$. However, bioethanol has a number of disadvantages, 
one of them being that it has low vapour pressure compared to gasoline, making engine starts difficult at low temperatures. In addition, bioethanol can cause corrosion in engines $[6,7]$.

Bioethanol production from starch-based biomass is dependent on the type of feedstock and the steps involved in the bioethanol production process [8]. In general, bioethanol production consists of five main steps, which are pre-treatment, hydrolysis, fermentation, distillation and dehydration [9]. The hydrolysis process breaks down the carbohydrates in the feedstock into sugar by using enzymes [10], and hydrolysis is often taken as the parameter of interest in the effort to improve bioethanol production. First-generation bioethanol feedstocks such as corn, sweet potatoes, cassava and sugar cane have raised concerns about global food security, and this hinders worldwide acceptance of using bioethanol as fuel for compression-ignition engines. Hence, much effort is being made to produce bioethanol from non-edible feedstocks [11-13].

Manihot glaziovii (M. glaziovii) has been shown to be a promising non-edible feedstock for bioethanol production because of its low cost and high starch content [14]. M. glaziovii holds high starch content of about $70 \%-85 \%$ by dry weight and high rate of production per hectare, and these properties are suitable for bioethanol production [15]. Moreover, $M$. glaziovii is drought-resistant and has a short growth cycle, and therefore it can be grown on marginal lands. M. glaziovii is native to tropical countries within Africa, South America, South Asia and Southeast Asia regions [16].

Response surface methodology (RSM) is a technique based on design of experiments (DOE). RSM is used to analyse the changes of the dependent variable (i.e., response variable) due to changes in the independent variables, and it is also used to optimize the dependent variable. RSM has been widely used to optimize the process parameters for bioethanol and biodiesel production [17-19]. RSM has been shown to be an efficient method to optimize every stage of the bioethanol production process, which significantly reduces time, costs and effort associated with conventional experimental techniques [20].

Studies of the starch-to-glucose hydrolysis process have been widely performed. The enzymatic starch hydrolysis process [21,22] and the acid hydrolysis process [23-25] still use conventional methods. Therefore, RSM optimization methods are used in the starch hydrolysis process into reducing sugar to obtain optimum conditions globally.

In this study, M. glaziovii starch is used as the feedstock to produce bioethanol. In addition, optimization of enzymatic hydrolysis is performed, with expectation of yielding the optimum quality of the produced reducing sugar. Response surface methodology based on the Box-Behnken experimental design was then used to optimize the operating parameters of the hydrolysis processes. Quadratic regression models were developed in this study and used to predict the reducing sugar concentration from hydrolysis. The physical and chemical properties of the M. glaziovii bioethanol were then measured according to the methods outlined in the ASTM D4806 standard $[9,26]$.

\section{Materials and Methods}

\subsection{Substrate and Enzymes}

M. glaziovii flour was sourced from North Sumatra, Indonesia. The M. glaziovii tubers was first peeled and washed to remove impurities, and then cut and shredded. The shredded M. glaziovii was added to water, transforming into wet starch. The wet starch was dried in an oven at a temperature of $50{ }^{\circ} \mathrm{C}$ for $48 \mathrm{~h}$. This drying process is important for longer storage periods at $25^{\circ} \mathrm{C}$. The dried starch was then milled and sifted to obtain starch with a homogeneous particle size.

Enzyme $\alpha$-amylase from Bacillus licheniformis Type XII-A and amyloglucosidase from Aspergillus niger are used as a catalyst liquefaction and saccharification. Both enzymes were purchased from Sigma-Aldrich (St. Louis, MO, USA), with enzymatic activity of more than or equal to $500 \mathrm{U} / \mathrm{g}$ protein for $\alpha$-amylase and greater than or equal to $300 \mathrm{U} / \mathrm{mL}$ for amyloglucosidase. 


\subsection{Methodology}

\subsubsection{Composition of Manihot glaziovii Substrate}

The composition of the M. glaziovii starch was measured at Bioethanol Laboratory, Faculty of Engineering, University of Malaya. The composition of M. glaziovii starch was measured according to the methods outlined in the AAAC International Approved Methods of Analysis.

\subsubsection{Analysis of Sugars and Ethanol as by-Products}

The reducing sugar content was analyzed using the 3,5-dinitrosalisilat acid (DNS) method [27]. The amount of reducing sugar was determined using an ultraviolet-visible (UV-Vis) spectrophotometer (SPEKOL ${ }^{\circledR} 1500$, Analytik Jena, Berlin, Germany). Ethanol concentration is the concentration of ethanol at the end of fermentation. It was measured with a gas chromatograph (7890A, Agilent, Santa Clara, CA, USA) system with a thermal conductivity detector and $30 \mathrm{~m} \times 0.32 \mathrm{~mm}$, DB-ALC2 column (Agilent) with He as carrier gas, the injector temperature and detector temperature were $150{ }^{\circ} \mathrm{C}$ and $200{ }^{\circ} \mathrm{C}$, respectively.

\subsubsection{Hydrolysis Process}

The general procedure of enzymatic hydrolysis was initiated by preparing the respective substrates in a flask filled with distilled water. The liquefaction process involved $M$. glaziovii starch $(10 \%, 17.5 \%$ and $25 \%(w / v))$ and $(90,100$ and $110 \mathrm{U} / \mathrm{g})$ of $\alpha$-amylase at $90^{\circ} \mathrm{C}$, stroke speed 50,90 and $130 \mathrm{spm}$. The liquefaction process was followed by a saccharification process with amyloglucosidase (36, 51 and $66 \mathrm{U} / \mathrm{mL}$ ) at $70^{\circ} \mathrm{C}$ for $240 \mathrm{~min}$. Each sample was then centrifuged at 10,000 rpm for $5 \mathrm{~min}$ to separate the solid residue and then to test the DNS method to measure the amount of reducing sugar in each hydrolyzate. The optimization of $M$. glaziovii enzymatic hydrolysis was initiated.

\subsubsection{Optimization of Hydrolysis Process}

Response surface methodology based on Box-Behnken experimental design was used to optimize the operating parameters of the starch hydrolysis process. The Box-Behnken experimental design is one of the optimization tools available in the design expert software version 9.0.4.1 (Stat-Ease Inc., Minneapolis, MN, USA). The independent variables chosen for optimization are as follows: substrate loading (10\%, $17.5 \%$ and $25 \%(w / v))$, $\alpha$-amylase concentration $(90,100$ and $110 \mathrm{U} / \mathrm{g})$, amyloglucosidase concentration (36, 51 and $66 \mathrm{U} / \mathrm{mL}$ ) and stroke speed (50, 90 and 130 strokes/min, spm). The coded levels of the independent variables (factor variables) used for hydrolysis of M. glaziovii starch are presented in Table 1 and the Box-Behnken experimental design of the starch hydrolysis process is presented in Table 5.

Table 1. Coded levels of the independent variables used for hydrolysis of Manihot glaziovii (M. glaziovii) starch.

\begin{tabular}{ccccc}
\hline \multirow{2}{*}{ Parameter } & Unit & \multicolumn{3}{c}{ Range and Levels } \\
\cline { 3 - 5 } & & $\mathbf{- 1}$ & $\mathbf{0}$ & $\mathbf{+ 1}$ \\
\hline Substrate loading $\left(X_{1}\right)$ & $\%(w / v)$ & 10 & 17.5 & 25 \\
$\alpha$-amylase concentration $\left(X_{2}\right)$ & $\mathrm{U} / \mathrm{g}$ & 90 & 100 & 110 \\
Amyloglucosidase concentration $\left(X_{3}\right)$ & $\mathrm{U} / \mathrm{mL}$ & 36 & 51 & 66 \\
Stroke speed $\left(X_{4}\right)$ & $\mathrm{spm}$ & 50 & 90 & 130 \\
\hline
\end{tabular}

The experimental data were analyzed using response surface regression. Also, analysis of variance (ANOVA) was used to assess the quality of the model fit. The quadratic response surface model for the reducing sugar concentration is given by Equation (1):

$$
\begin{aligned}
& Y_{\mathrm{RS}}=\beta_{0}+\beta_{1} X_{1}+\beta_{2} X_{2}+\beta_{3} X_{3}+\beta_{4} X_{4}+\beta_{12} X_{1} X_{2}+\beta_{13} X_{1} X_{3}+\beta_{14} X_{1} X_{4}+\beta_{23} X_{2} X_{3}+\beta_{24} X_{2} X_{4} \\
& +\beta_{34} X_{3} X_{4}+\beta_{11} X_{1}^{2}+\beta_{22} X_{2}^{2}+\beta_{33} X_{3}^{2}+\beta_{44} X_{4}^{2}
\end{aligned}
$$


In Equation (1), $Y_{\mathrm{RS}}$ is the response variable, which in this case is the reducing sugar concentration $(\mathrm{g} / \mathrm{L}), \beta_{0}$ is the intercept term, $\beta_{1}, \beta_{2}, \beta_{3}$ and $\beta_{4}$ are linear coefficients, $\beta_{12}, \beta_{13}, \beta_{14}, \beta_{23}, \beta_{24}$ and $\beta_{34}$ are interactive coefficients, $\beta_{11}, \beta_{22}, \beta_{33}$ and $\beta_{44}$ are quadratic coefficients, and $X_{1}, X_{2}, X_{3}$ and $X_{4}$ are the coded independent variables. In this case, $X_{1}$ represents the substrate loading $(\%(w / v))$, $X_{2}$ represents the $\alpha$-amylase concentration $(\mathrm{U} / \mathrm{g}), X_{3}$ represents the amyloglucosidase concentration $(\mathrm{U} / \mathrm{mL})$ and $X_{4}$ represent stroke speed (strokes per minute, spm).

\subsubsection{Yeast Culturing Media Preparation}

The yeast of Saccharomyces cerevisiae (S. cerevisiae) Type II, which was purchased from Sigma-Aldrich, was used to ferment the M. glaziovii starch into ethanol. Yeast peptone dextrose was used for cultivating and maintaining dry yeast from $S$. cerevisiae. The yeast peptone dextrose was prepared by $2 \mathrm{~g}$ of yeast extract, $4 \mathrm{~g}$ bacterial peptone, $4 \mathrm{~g}$ of glucose and $12 \mathrm{~g}$ agar in $200 \mathrm{~mL}$ of distilled water. Then, dry yeast was activated by adding $100 \mathrm{~mL}$ of distilled water in flask. The solution was sterilized in an autoclave for $35 \mathrm{~min}$ and it was placed and maintained on a glass petri dish. The yeast is kept in an incubator at a temperature of $37^{\circ} \mathrm{C}$ for $48 \mathrm{~h}$ in order to make it occulated before being used for bioethanol production.

\subsubsection{Fermentation Process}

The fermentation process was carried out in $250 \mathrm{~mL}$ Erlenmeyer flasks. Each flask containing hydrolysed $M$. glaziovii starch was mixed with the following fermentation nutrients: $1 \mathrm{~g}$ of yeast extract, $0.4 \mathrm{~g}$ of potassium dihydrogen phosphate $\left(\mathrm{KH}_{2} \mathrm{PO}_{4}\right)$ and $0.2 \mathrm{~g}$ of ammonium chloride $\left(\mathrm{NH}_{4} \mathrm{Cl}\right)$ for every $100 \mathrm{~mL}$ of hydrolysate. The solutions were mixed and then sterilized at a temperature of $125^{\circ} \mathrm{C}$ by autoclave for $35 \mathrm{~min}$. The sterilized solutions were then inoculated with $S$. cerevisiae yeast. Then, the flasks were placed in an incubator shaker. Finally, the flasks were placed in an incubator shaker at $37^{\circ} \mathrm{C}$, agitation $120 \mathrm{rpm}$ for $84 \mathrm{~h}$ for the fermentation process. Samples were taken after 12, 24, 36, 48, 60,72 and $84 \mathrm{~h}$.

\subsubsection{Fermentation Kinetics}

Modified Gompertz's equation was used to determine the fermentation kinetics of the M. glaziovii starch [28], which is expressed as:

$$
C_{\mathrm{e}}=C_{\mathrm{e} \cdot \max } \times \exp \left\{-\exp \left[\frac{R_{\mathrm{e} \cdot \max } \times \exp (1)}{C_{\mathrm{e} \cdot \max }}\right] \times\left(t_{\mathrm{L}}-t\right)+1\right\}
$$

where $C_{\mathrm{e}}$ is the predicted ethanol concentration $(\mathrm{g} / \mathrm{L}), C_{\mathrm{e} \cdot \max }$ is the maximum ethanol concentration $(\mathrm{g} / \mathrm{L}), R_{\mathrm{e} . m a x}$ is the maximum ethanol production rate $(\mathrm{g} / \mathrm{L} / \mathrm{h}), t_{\mathrm{L}}$ is the lag phase time $(\mathrm{h})$, and $t$ is the independent variable of time (h).

\subsubsection{Distillation Process}

The ethanol extraction process was carried out in two stages: distillation and dehydration. Distillation was carried out using a rotary evaporator at a temperature, pressure and rotary speed of $60{ }^{\circ} \mathrm{C}, 175 \mathrm{mbar}$ and $100 \mathrm{rpm}$, respectively. The vaporized fermentation solution was vacuumed by a pump and flowed to the other end to be condensed, resulting in an improved quality of ethanol solution. Following that, dehydration process using zeolite was performed. Zeolite was introduced into the dehydration column with diameter of 1 inch and the height of the zeolite is $90 \%(w / v)$.

\subsubsection{Fourier Transform Infrared Spectroscopy}

Fourier transform infrared (FTIR) spectroscopy is a powerful analytical technique to examine the functional groups of an alcohol, therefore FTIR (Tensor 27, Bruker, Billerica, MA, USA) was utilized to identify the limits of the chemical structure of M. glaziovii bioethanol. The produced bioethanol 
M. glaziovii was analyzed by attenuated total reflection (ATR) sample compartment with mid-infrared (MIR) spectra in the wavenumber range of $4000-400 \mathrm{~cm}^{-1}$.

\subsubsection{Physical and Chemical Properties of the Manihot glaziovii Bioethanol}

The physical and chemical properties of the bioethanol produced from the inedible M. glaziovii feedstock were tested according to the methods outlined in ASTM D4806 standard. The equipment used to analyze the physical and chemical properties of the bioethanol are summarized in Table 2.

Table 2. List of equipment used to analyse the properties of the M. glaziovii bioethanol. CHN: carbon, hydrogen, nitrogen.

\begin{tabular}{ccc}
\hline Property & Equipment & Standard Method [9,26] \\
\hline $\begin{array}{c}\text { Kinematic viscosity } \\
\text { Density }\end{array}$ & $\begin{array}{c}\text { Lovis 2000 M/ME micro viscometer and } \\
\text { micro density meter (Anton Paar) }\end{array}$ & $\begin{array}{c}\text { DIN 53015 } \\
\text { ISO 12058 }\end{array}$ \\
\hline $\begin{array}{c}\text { Elemental analysis for carbon (C), } \\
\text { hydrogen (H) and oxygen (O) }\end{array}$ & CE-440 CHN Elemental Analyzer (EIA) & ASTM D5291 \\
\hline Calorific value & IKA C2000 basic, automatic bomb \\
calorimeter & ASTM D240 \\
\hline Ethanol content & Gas chromatograph, Agilent 7890A & ASTM D4806 \\
\hline
\end{tabular}

\section{Results and Discussion}

\subsection{Composition of Manihot glaziovii Substrate}

The M. glaziovii starch was stored in a closed container in a refrigerator before the laboratory experiment was conducted. The M. glaziovii starch consisted of particles with diameter 125-150 $\mu \mathrm{m}$ (98\% or more particles pass through a $150 \mu \mathrm{m}$ sieve). The content of the main components in the M. glaziovii starch was determined by chemical analysis (Table 3). The presence of more than $70 \mathrm{wt} \%$ of carbohydrates in the biomass makes it a potential substrate for bioethanol fuels.

Table 3. The substrate components of M. glaziovii.

\begin{tabular}{ccc}
\hline Parameter & Unit & M. glaziovii \\
\hline carbohydrates & wt \% & 74.8 \\
proteins & wt \% & 6.62 \\
lipids & wt \% & 3.12 \\
Ash & wt \% & 5.15 \\
fibers & wt \% & 1.70 \\
moisture content & wt \% & 8.61 \\
\hline
\end{tabular}

\subsection{Optimization of Starch Hydrolysis Process Operating Parameters}

Once the optimal hydrolysis process is determined, the Box-Behnken design is used to test four different independent variables in the hydrolysis process. ANOVA was used to determine the effects of the independent variables (i.e., substrate loading, $\alpha$-amylase concentration, amyloglucosidase concentration and stroke speed) on the dependent variable (i.e., reducing sugar concentration).

Table 4 showed that the regression coefficients of the linear terms $X_{1}, X_{2}$, and $X_{3}$ were significant at the $1 \%$ level as well as quadratic coefficients of $X_{1}^{2}$. The regression coefficients of the linear term $X_{4}$, $X_{2} X_{4}$ and $X_{3} X_{4}$ were significant at the $5 \%$ level as well as quadratic coefficients of $X_{2}^{2}$. The polynomial model for reducing sugar concentration was regressed by considering the significant terms and is shown in Equation (3) below:

$$
\begin{aligned}
& Y_{\mathrm{RS}}=-886.67279+10.19401 X_{1}+15.62925 X_{2}-0.77128 X_{3}+0.91738 X_{4}-0.012025 X_{2} X_{4} \\
& +0.009287 X_{3} X_{4}-0.27024 X_{1}^{2}-0.07333 X_{2}^{2}
\end{aligned}
$$


In Equation (3), $Y_{\mathrm{RS}}$ represents the reducing sugar concentration (g/L), $X_{1}$ represents the substrate loading, $X_{2}$ represents the $\alpha$-amylase concentration, $X_{3}$ represents the amyloglucosidase concentration and $X_{4}$ represents the stroke speed.

The ANOVA results for the starch hydrolysis process are presented in Table 4. The reducing sugar concentrations were predicted using Equation (3) for each sample and the results are shown in Table 5.

Table 4. Analysis of variance (ANOVA) results for the starch hydrolysis process. C.V.: coefficient of variation.

\begin{tabular}{|c|c|c|c|c|c|c|}
\hline Source & Sum of Squares & $d f$ & Mean Square & $F$ Value & $p$-Value Prob $>F$ & Remarks \\
\hline A-Substrate loading $\left(X_{1}\right)$ & $22,057.47$ & 1 & $22,057.47$ & 1240.98 & $<0.0001$ & - \\
\hline C-Amyloglucosidase $\left(X_{3}\right)$ & 2528.51 & 1 & 2528.51 & 142.26 & $<0.0001$ & - \\
\hline D-Stroke speed $\left(X_{4}\right)$ & 91.69 & 1 & 91.69 & 5.16 & 0.0394 & - \\
\hline $\mathrm{AB}$ & 39.38 & 1 & 39.38 & 2.22 & 0.1588 & - \\
\hline $\mathrm{BC}$ & 16.61 & 1 & 16.61 & 0.93 & 0.3502 & - \\
\hline $\mathrm{BD}$ & 92.54 & 1 & 92.54 & 5.21 & 0.0387 & - \\
\hline CD & 124.21 & 1 & 124.21 & 6.99 & 0.0193 & - \\
\hline$A^{2}$ & 1498.9 & 1 & 1498.9 & 84.33 & $<0.0001$ & - \\
\hline $\mathrm{B}^{2}$ & 348.88 & 1 & 348.88 & 19.63 & 0.0006 & - \\
\hline Pure Error & 17.18 & 4 & 4.3 & - & - & - \\
\hline Cor Total & $28,938.71$ & 28 & - & - & - & - \\
\hline$R$-Squared & 0.9914 & - & Adj $R$-Squared ${ }^{\text {a }}$ & 0.9828 & - & - \\
\hline C.V. ${ }^{\mathrm{b}} \%$ & 3.05 & - & - & - & - & - \\
\hline
\end{tabular}

Notes: ${ }^{\text {a }}$ Adjusted $R^{2} ;{ }^{\mathrm{b}}$ Coefficient of variation.

Table 5. Box-Behnken experimental design for the starch hydrolysis process.

\begin{tabular}{|c|c|c|c|c|c|c|}
\hline \multirow{2}{*}{$\begin{array}{c}\text { Sample } \\
\text { No }\end{array}$} & \multirow{2}{*}{$\begin{array}{c}\text { Substrate } \\
\text { Loading } \\
(\% \text { w/v })\left(X_{1}\right)\end{array}$} & \multirow{2}{*}{$\begin{array}{l}\alpha \text {-Amylase } \\
\text { Concentration } \\
(U / g)\left(X_{2}\right)\end{array}$} & \multirow{2}{*}{$\begin{array}{c}\text { Amyloglucosidase } \\
\text { Concentration } \\
(\mathrm{U} / \mathrm{mL})\left(X_{3}\right)\end{array}$} & \multirow{2}{*}{$\begin{array}{l}\text { Stroke Speed } \\
(\mathrm{spm})\left(X_{4}\right)\end{array}$} & \multicolumn{2}{|c|}{ Reducing Sugar (g/L) } \\
\hline & & & & & Experiment & Predicted \\
\hline 1 & 25 & 90 & 51 & 90 & 153.84 & 152.78 \\
\hline 2 & 10 & 100 & 36 & 90 & 78.84 & 75.92 \\
\hline 3 & 10 & 100 & 51 & 130 & 88.48 & 91.36 \\
\hline 4 & 17.5 & 90 & 36 & 90 & 110.68 & 114.29 \\
\hline 5 & 25 & 100 & 51 & 130 & 180.52 & 178.27 \\
\hline 6 & 17.5 & 100 & 36 & 50 & 138.46 & 134.07 \\
\hline 7 & 17.5 & 110 & 51 & 50 & 160.28 & 155.00 \\
\hline 8 & 17.5 & 100 & 51 & 90 & 149.64 & 148.62 \\
\hline 9 & 17.5 & 100 & 66 & 130 & 164.94 & 168.63 \\
\hline 10 & 17.5 & 100 & 66 & 50 & 150.48 & 151.96 \\
\hline 11 & 25 & 100 & 51 & 50 & 170.28 & 171.57 \\
\hline 12 & 17.5 & 100 & 36 & 130 & 130.63 & 128.45 \\
\hline 13 & 17.5 & 90 & 51 & 50 & 118.82 & 119.30 \\
\hline 14 & 17.5 & 110 & 66 & 90 & 168.84 & 169.40 \\
\hline 15 & 17.5 & 90 & 51 & 130 & 132.64 & 134.45 \\
\hline 16 & 17.5 & 100 & 51 & 90 & 148.58 & 148.62 \\
\hline 17 & 17.5 & 100 & 51 & 90 & 145.24 & 148.62 \\
\hline 18 & 10 & 110 & 51 & 90 & 92.75 & 93.11 \\
\hline 19 & 25 & 100 & 36 & 90 & 158.85 & 158.92 \\
\hline 20 & 17.5 & 100 & 51 & 90 & 150.78 & 148.62 \\
\hline 21 & 17.5 & 100 & 51 & 90 & 148.84 & 148.62 \\
\hline 22 & 17.5 & 110 & 51 & 130 & 154.86 & 150.91 \\
\hline 23 & 25 & 110 & 51 & 90 & 182.64 & 185.13 \\
\hline 24 & 25 & 100 & 66 & 90 & 191.25 & 190.70 \\
\hline 25 & 17.5 & 110 & 36 & 90 & 130.49 & 136.30 \\
\hline 26 & 17.5 & 90 & 66 & 90 & 140.88 & 139.24 \\
\hline 27 & 10 & 100 & 51 & 50 & 80.58 & 87.00 \\
\hline 28 & 10 & 90 & 51 & 90 & 76.5 & 73.30 \\
\hline 29 & 10 & 100 & 66 & 90 & 105.75 & 102.21 \\
\hline
\end{tabular}


ANOVA was carried out to determine the statistical significance of the quadratic response surface model, and it can be seen from Table 4 that the $p$-value of the model was less than 0.0001, which indicates the model was statistically significant. The coefficient of determination $\left(R^{2}\right)$ was found to be 0.9914 , which indicates that $99.14 \%$ of the experimental data were relevant and only $0.86 \%$ of the total variations was not explained by the model. In general, a high value of $R^{2}$ indicates that there is good fit between the predicted data and experimental data.

The adjusted coefficient of determination $\left(R_{a}^{2}\right)$ was found to be very high with a value of 0.9828 , which indicates that that the model accounted for $98.28 \%$ of the variability in the data. The coefficient of variation (C.V.) was found to be $3.05 \%$, indicating that the deviations between the predicted data and experimental data were small. The lack of fit was found to be small with a value of 5.39, and this indicates that the model adequately described the relationship between the dependent variable (i.e., reducing sugar concentration) and the independent variables (i.e., substrate loading, $\alpha$-amylase concentration, amyloglucosidase concentration and stroke speed). The corresponding $p$-value for the lack of fit parameter was 0.0593 ( $p$-value $>\alpha$ ), which indicates that there was no evidence that the model did not fit the experimental data.

From the experimental result inputs, the optimum conditions for enzymatic hydrolysis were generated by DOE. The optimum substrate loading, $\alpha$-amylase concentration, amyloglucosidase concentration and stroke speed were $23.88 \%(w / v), 109.43 \mathrm{U} / \mathrm{g}, 65.44 \mathrm{U} / \mathrm{mL}$ and $74.87 \mathrm{spm}$, respectively. The optimum reducing sugar was found to be $196.23 \mathrm{~g} / \mathrm{L}$. Verification tests in triplicate were performed under the set of optimized parameters. Average reducing sugar of $194.98 \mathrm{~g} / \mathrm{L}$ was achieved, at predicted optimum conditions of the variables.

The predicted reducing sugar concentrations are plotted against the experimental values, as shown in Figure 1. It can be observed that all of the data points lie within the proximity of the regression line, which indicates that there is good agreement between the predicted and experimental data.

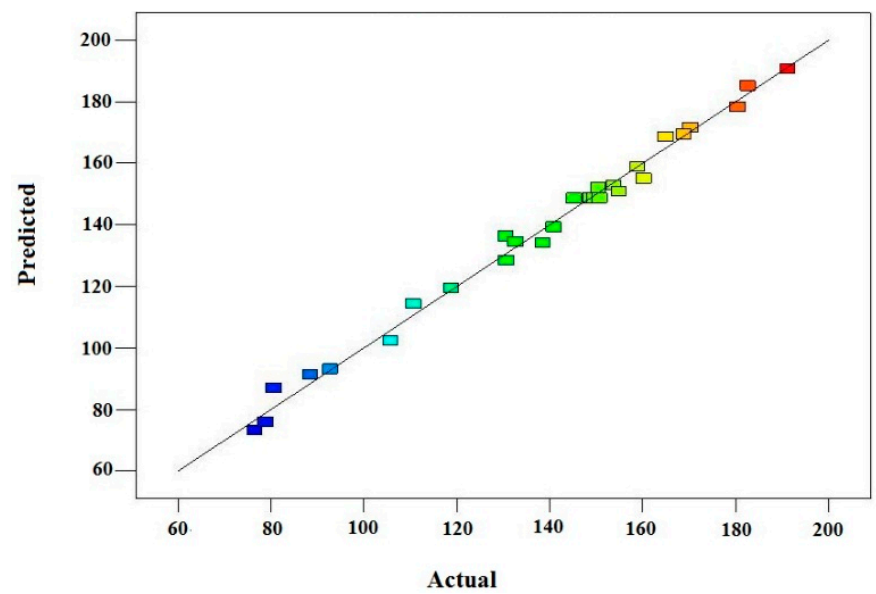

Figure 1. Predicted versus experimental of reducing sugar concentration.

\subsection{Relationship between the Independent Variables of the Starch Hydrolysis Process}

In this study, the operating parameters of the starch hydrolysis process (i.e., substrate loading, $\alpha$-amylase concentration, amyloglucosidase concentration and stroke speed) were varied in order to determine the interaction effects of these parameters on the produced reducing sugar concentration. The results are presented in the form of three-dimensional surface plots. Figure $2 \mathrm{a}-\mathrm{c}$ illustrates that there were significant interactions between substrate loading and other process parameters affecting the results of reducing sugar. Figure $2 \mathrm{a}-\mathrm{c}$ showed that the substrate loading had a more significant influence on the results of reducing sugar compared with stroke speed, $\alpha$-amylase concentration and amyloglucosidase concentration. In general, an increase in the substrate loading hastened the improvement of reducing sugar concentration. However, an increase in stroke speed had an insignificant 
effect on the reducing sugar concentration, and it was evident that for a fixed substrate loading, increasing the stroke speed would only increase reducing sugar production by a slight amount. Figure $2 \mathrm{a}-\mathrm{c}$ indicates that high reducing sugar results could be achieved on a substrate loading amounted to $23.88 \%(w / v)$.

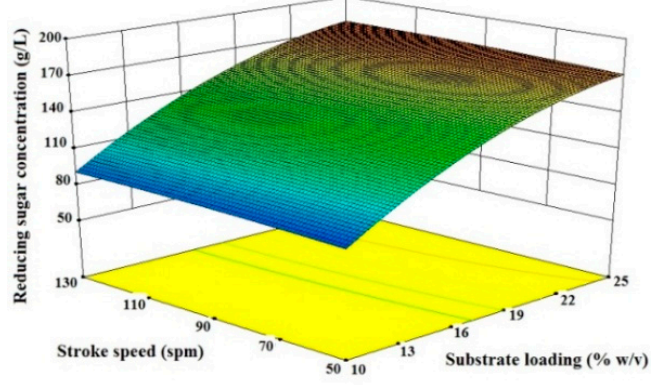

(a)

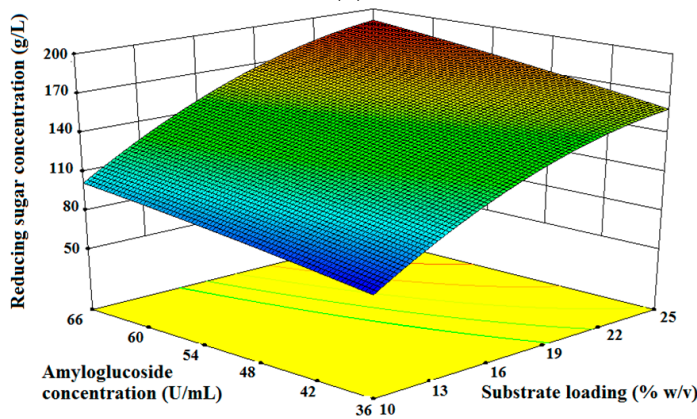

(c)

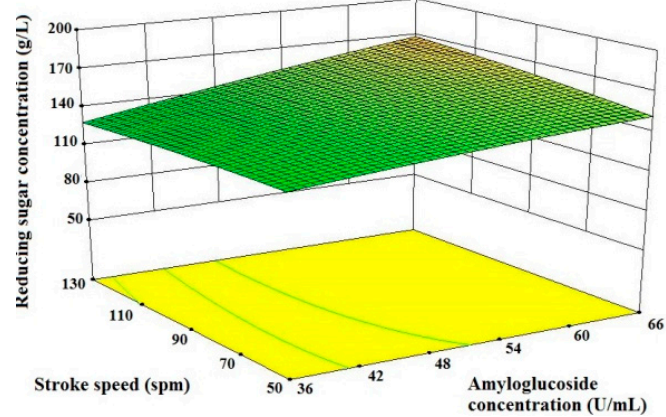

(e)

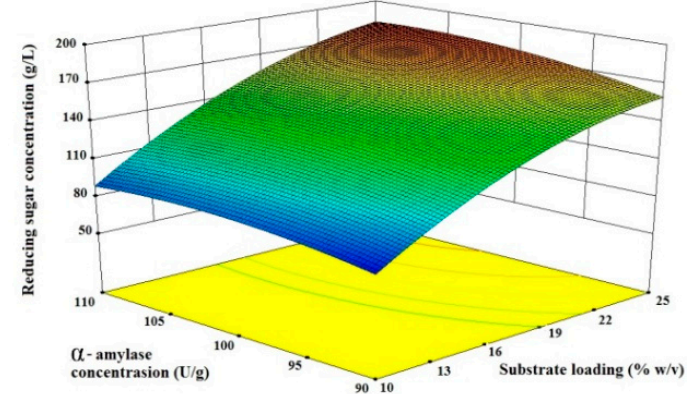

(b)

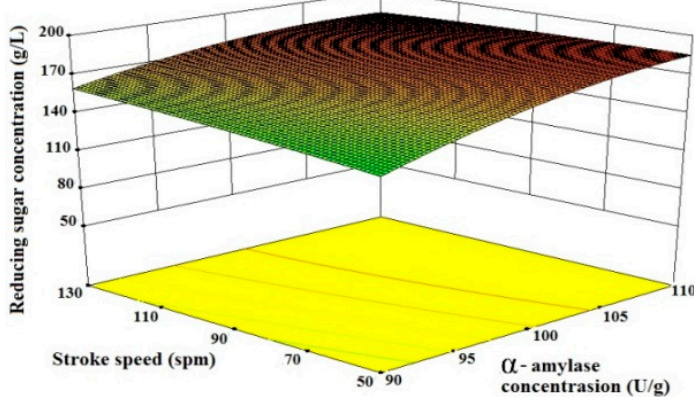

(d)

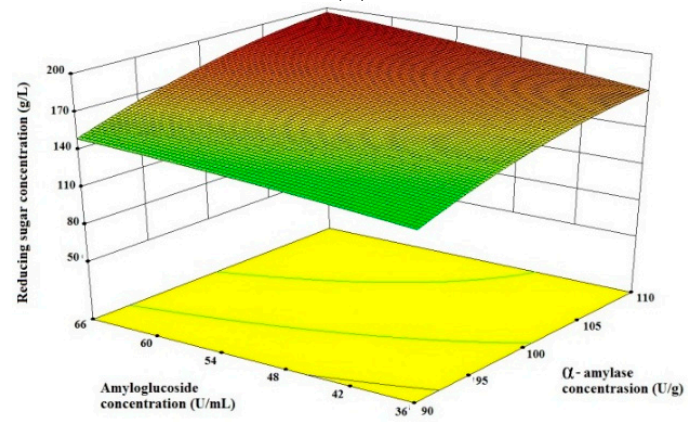

(f)

Figure 2. Three-dimensional surface plot of reducing sugar concentration for: (a) substrate loading and stroke speed; (b) substrate loading and $\alpha$-amylase concentration; (c) substrate loading and amyloglucosidase concentration; (d) $\alpha$-amylase concentration and stroke speed; (e) amyloglucosidase concentration; and stroke speed; and (f) amyloglucosidase concentration and $\alpha$-amylase concentration

Figure $2 b$, $d$, $f$ showed there were significant interactions between $\alpha$-amylase concentration and other process parameters that affected the results of reducing sugar. Figure $2 b, d, f$ showed that high reducing sugar results could be achieved at a concentration of $\alpha$-amylase amounted to $109.43 \mathrm{U} / \mathrm{g}$. Figure $2 \mathrm{~b}$ showed that at high substrate loading, the result of reducing sugar increased significantly with increased $\alpha$-amylase concentration. It is also shown in Figure $2 \mathrm{f}$ that increased $\alpha$-amylase concentration which was followed by an increase in amyloglucosidase concentration also produced maximum reducing sugar.

Figure $2 c, e, f$ showed there were significant interactions of amyloglucosidase concentration with other process parameters that affected the results of reducing sugar. This can be seen in Figure 2c,e,f, which shows that high reducing sugar results could be achieved at $65.44 \mathrm{U} / \mathrm{mL}$ amyloglucosidase 
concentration. However, in Figure 2e showed that the increase in stroke speed did not have a significant impact on increasing the reducing sugar.

The hydrolysis process (liquefaction and saccharification) for M. glaziovii starch is a process for converting starch molecules into reducing sugar that is carried out by the enzyme $\alpha$-amylse and amyloglucosidase. Figure $2 b, c$ shows reducing sugar levels rise with increasing concentration of the enzyme $\alpha$-amylse and amyloglucosidase used in the hydrolysis process. This is due to the enzyme $\alpha$-amylse and amyloglucosidase hydrolyzing $\alpha$-1,4-glucoside and $\alpha$-1,6-glucoside producing reducing sugar. From Figure 2a-f, the maximum concentration reducing sugar produced was $196.23 \mathrm{~g} / \mathrm{L}(82 \%)$ when the substrate loading, $\alpha$-amylase, amyloglucosidase concentration and stroke speed were $23.88 \%$ $(w / v), 109.43 \mathrm{U} / \mathrm{g}, 65.44 \mathrm{U} / \mathrm{mL}$ and $74.87 \mathrm{spm}$, respectively. The results of reducing in this study are similar to a study by Naguleswaran et al. [25], with corn and triticale $(80.8 \%-84.5 \%)$ as a feedstock, but slightly lower than that of wheat $(90.8 \%-95.1 \%)$. Gumienna et al. [22] also conduct the enzyme hydrolysis for corn starch and obtained reducing sugar of $11.7 \mathrm{~g} / \mathrm{L}(69.40 \%)$. Moreover, Tasić et al. [24] performed acid hydrolysis on potato and produced a $114 \mathrm{~g} / \mathrm{L}(64 \%)$ concentration of reducing sugar. It was showed that optimization of hydrolysis improved the reducing sugar and increased ethanol yield.

\subsection{Ethanol Production from Manihot glaziovii}

The highest initial sugar from the hydrolysis process (Section 3.2) was fermented to produce bioethanol. The production of bioethanol in this study was conducted by batch fermentation. Figure 3 shows the production of ethanol from fermentation process by S. cerevisiae cultivated in M. glaziovii starch solution. During the first $12 \mathrm{~h}$ to $84 \mathrm{~h}$ of fermentation, reducing sugar consumed in M. glaziovii starch solution changed rapidly. After completing $84 \mathrm{~h}$ of fermentation, an ethanol production conversion ratio of $0.41-0.45 \mathrm{~g}$ ethanol/g reducing sugar was observed, which is equivalent to $81.94 \%-88.61 \%$ of theoretical ethanol yield ( $0.51 \mathrm{~g}$ ethanol/g reducing sugar). This also produced an ethanol concentration of $86.37 \mathrm{~g} / \mathrm{L}$ after $84 \mathrm{~h}$ fermentation. The result for ethanol yields in this study was similar to study of Moshi et al. [14] and a little higher, where their ethanol yield was $82 \%-84 \%$ of theoretical ethanol yield. However, it was slightly lower than the results of the study Moshi et al. [15,29] which are equal to $95 \%$ and $94 \%$. In addition, it was slightly higher when compared with the results of a study by Sivamani et al. [30], where they used cassava peel and ethanol yield was $83 \%$ of the theoretical ethanol yield. The same is true when the result is compared with the study by Gumienna et al. [22] where the outcome of each was $81.33 \%$.

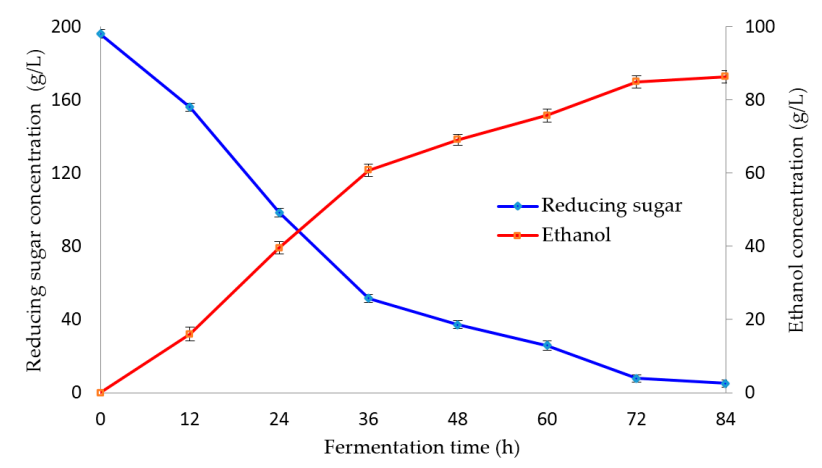

Figure 3. Ethanol and reducing sugar concentration versus fermentation time with Saccharomyces cerevisiae (S. cerevisiae).

\subsection{Fermentation Kinetics}

In these fermentation conditions, the fermentation kinetics model was based on a modified Gompertz equation developed to describe dynamic change in ethanol concentration as a time function during ethanol fermentation. The kinetic model, which was obtained by nonlinear regression of experimental data using Microsoft Excel Solver, is given by: 


$$
C_{e}=87.47 \times \exp \left\{-\exp \left[\frac{1.84 \times \exp (1)}{87.47}\right] \times(2.94-t)+1\right\}
$$

where $C_{\mathrm{e}}$ is the ethanol concentration in $\mathrm{g} / \mathrm{L}$ and $t$ is the fermentation time in hours (h). According to Equation (4), the maximum ethanol concentration was $87.47 \mathrm{~g} / \mathrm{L}$, maximum reaction rate was $1.84 \mathrm{~g} / \mathrm{L} / \mathrm{h}$ and the lag time period was $2.94 \mathrm{~h}$. The predicted ethanol concentrations using the kinetic model agreed well with the measured ethanol concentrations as shown in Figure 4 . The $R^{2}$ of the regression was 0.99 .

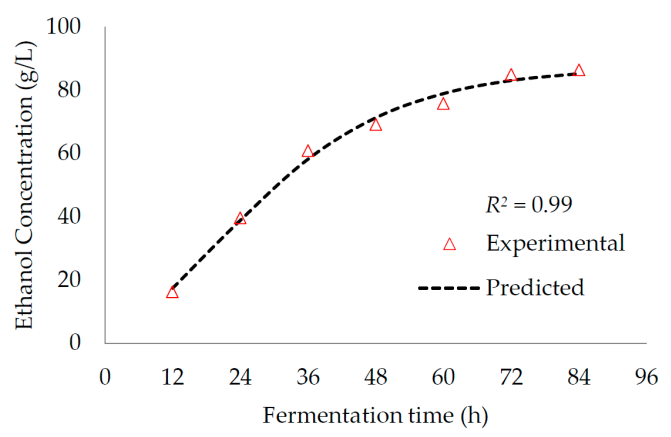

Figure 4. Fitting of modified Gompertz model to the experimental data for M. glaziovii ethanol production.

\subsection{Distillation and Dehydration}

Purification of ethanol has been done through a process of distillation and dehydration. In the distillation operation, ethanol obtained had a purity of $91.23 \%(v / v)$, and then we continued with dehydration process. Dehydration process used zeolite as an adsorbent with a mass of $90 \%(w / v)$; the greater the mass of adsorbent zeolite in a column, the more the height of the content of zeolite in the column increased. The resulting contact between ethanol solution with zeolite solution took more time, so that more water molecules were absorbed into the zeolite pores. The dehydration process resulted in $95.6 \%(v / v)$ ethanol, 3.9\% higher than Moshi et al. [21].

\subsection{Fourier Transform Infrared Spectroscopy of Manihot glaziovii Bioethanol}

Figure 5 illustrates the results of FTIR spectroscopy test of M. glaziovii bioethanol. Infrared absorption by O-H groups is indicated in $3355 \mathrm{~cm}^{-1}$ absorption wave; this condition shows that the broad $\mathrm{O}-\mathrm{H}$ stretching vibration is very strong, and this is the same as the research by Yadira et al. [31]. Peak at $2977 \mathrm{~cm}^{-1}$ represents a stretching $\mathrm{C}-\mathrm{H}$ bond. In addition, the existence of an absorption wave at the $1645 \mathrm{~cm}^{-1}$ region shows the presence of an alkene group with variable $\mathrm{C}=\mathrm{C}$ bonds. Absorption at the $1453 \mathrm{~cm}^{-1}$ wave shows there is an alkane group with bonds between atoms $\mathrm{C}-\mathrm{H}$ in the form of $\mathrm{CH}_{3}$ with medium intensity. The wave of $1320-1000 \mathrm{~cm}^{-1}$ shows the presence of ether groups to stretch the $\mathrm{C}-\mathrm{C}$ bond, which is strong enough.

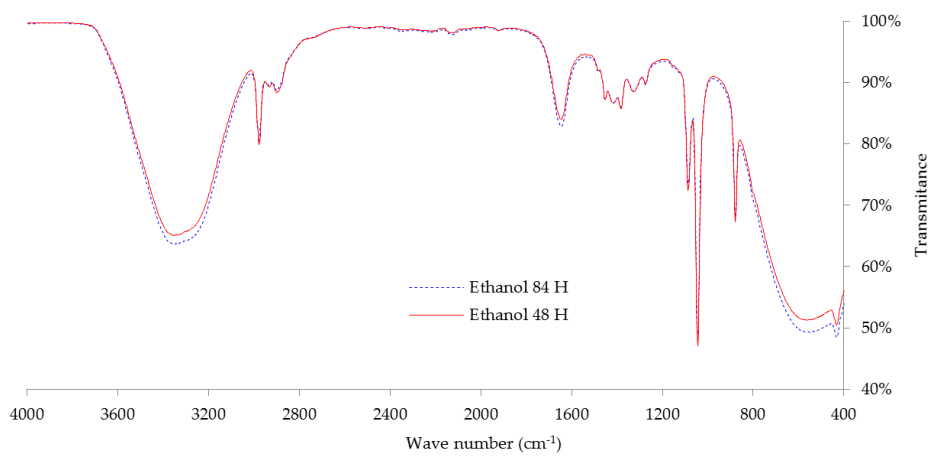

Figure 5. Fourier transform infrared spectrum of M. glaziovii bioethanol. 


\subsection{Physical and Chemical Properties of Manihot glaziovii Bioethanol}

In general, the physical and chemical properties of the bioethanol indicate the quality of fuel used for internal combustion engines. In this study, the physical and chemical properties of M. glaziovii bioethanol were determined in accordance with the methods stipulated in the ASTM D4806 standard, and the properties are compared with those of gasoline and reference ethanol, as shown in Table 6. It can be seen that $M$. glaziovii bioethanol has an oxygen content of up to $35.1 \%$, and it can improve the efficiency of combustion at high temperatures of combustion. In addition, the lower $\mathrm{C} / \mathrm{H}$ atom ratio of M. glaziovii bioethanol decreases its adiabatic flame temperature, which leads to perfect combustion.

Table 6. Comparison of the properties of M. glaziovii bioethanol, gasoline and ethanol.

\begin{tabular}{cccc}
\hline Fuel Properties & M. glaziovii Bioethanol & Gasoline [26] & Ethanol ASTM D4806 [26] \\
\hline Formula & $\mathrm{C}_{2} \mathrm{H}_{5} \mathrm{OH}$ & $\mathrm{C}_{5}-\mathrm{C}_{12}$ & $\mathrm{C}_{2} \mathrm{H}_{5} \mathrm{OH}$ \\
Carbon-fraction & 56.1 & $85-88$ & 52.2 \\
Hydrogen-fraction & 12.5 & $12-15$ & 13 \\
Oxygen-fraction & 35.1 & 0 & 34.7 \\
$\mathrm{C} / \mathrm{H}($ atom ratio) & 0.37 & 0.56 & 0.33 \\
Viscosity at $20^{\circ} \mathrm{C}\left(\mathrm{mm} / \mathrm{s}^{2}\right)$ & 1.28 & $0.5-0.6$ & $1.2-1.5$ \\
Density at $15^{\circ} \mathrm{C}\left(\mathrm{kg} / \mathrm{m}^{3}\right)$ & 803.7 & $750-765$ & $785-809.9$ \\
Higher heating value $(\mathrm{MJ} / \mathrm{kg})$ & 30.26 & 47.30 & 29.7 \\
Lower heating value MJ $/ \mathrm{kg}$ & 28.98 & 44 & 26.9 \\
Ethanol content $(\%$ vol. min) & 95.6 & - & 92.1 \\
\hline
\end{tabular}

\section{Conclusions}

This study is focused on optimizing the reducing sugar process parameters from a non-edible feedstock, M. glaziovii The operating parameters of the hydrolysis process (i.e., percentage of substrate loading, $\alpha$-amylase concentration, amyloglucosidase concentration and stroke speed) were optimized using response surface methodology in order to achieve the maximum reducing sugar concentration from hydrolysis of M. glaziovii starch. From this optimization, the observed optimum operating parameters for the hydrolysis process are as follows: $23.88 \%(w / v)$ substrate loading; $109.43 \mathrm{U} / \mathrm{g}$ $\alpha$-amylase concentration; $65.44(\mathrm{U} / \mathrm{mL})$ amyloglucosidase concentration and $74.87(\mathrm{spm})$ stroke speed. The results show that the substrate loading is the most important factor in reducing sugar production during hydrolysis. The quadratic response surface model predicted the optimum reducing sugar concentration to be $196.23 \mathrm{~g} / \mathrm{L}$, which is close to the experimental value of $194.98 \mathrm{~g} / \mathrm{L}$, which was obtained by running the hydrolysis with the optimum variables. In the latter part of the experiment, the optimized hydrolysate was brought to the fermentation process. The calculated ethanol concentration from the fermentation process using S. cerevisiae was found to be $86.37 \mathrm{~g} / \mathrm{L}$. From the optimization of enzymatic hydrolysis, it can be concluded that the selected parameters have a strong correlation with the reducing sugar production process, as proven by ANOVA analysis. Also, the results show that M. glaziovii has great potential for use as a non-edible feedstock for bioethanol production.

Acknowledgments: The authors gratefully acknowledge the financial support provided by the Ministry of Education of Malaysia and University of Malaya, Kuala Lumpur, Malaysia, under the High Impact Research Grant (Project title: Clean diesel technology for military and civilian transport vehicles, Grant No.: UM.C/HIR/MOE/ENG/07 D000007-16001), University Malaya Research Grant Scheme (Grant No.: RP022A-13AET), SATU Joint Research Scheme (RU021A-2015) and Postgraduate Research Grant, PPP (Grant No.: PG014-2015A).

Author Contributions: All the authors contributed to this work. Abdi Hanra Sebayang designed the study, performed the experiments, and prepared the first draft of the paper. Masjuki Haji Hassan, Hwai Chyuan Ong, Arridina Susan Silitonga, Teuku Meurah Indra Mahlia and Aditiya Harjon Bahar contributed to the conceptual approach and thoroughly revised the paper. Fitranto Kusumo contributed to developing the response surface methodology (RSM) analyses. Surya Dharma carried out the GC analyses and reducing sugar analyses by DNS method.

Conflicts of Interest: The authors declare no conflict of interest. 


\section{References}

1. Liguori, R.; Soccol, C.; De Souza Vandenberghe, L.P.; Woiciechowski, A.; Faraco, V. Second generation ethanol production from brewers' spent grain. Energies 2015, 8, 2575-2586. [CrossRef]

2. Renó, M.L.G.; Olmo, O.A.D.; Palacio, J.C.E.; Lora, E.E.S.; Venturini, O.J. Sugarcane biorefineries: Case studies applied to the brazilian sugar-alcohol industry. Energy Convers. Manag. 2014, 86, 981-991. [CrossRef]

3. Pejin, J.D.; Mojović, L.V.; Pejin, D.J.; Kocić-Tanackov, S.D.; Savić, D.S.; Nikolić, S.B.; Djukić-Vuković, A.P. Bioethanol production from triticale by simultaneous saccharification and fermentation with magnesium or calcium ions addition. Fuel 2015, 142, 58-64. [CrossRef]

4. Hansdah, D.; Murugan, S.; Das, L.M. Experimental studies on a DI diesel engine fueled with bioethanol-diesel emulsions. Alexandria Eng. J. 2013, 52, 267-276. [CrossRef]

5. Wang, J.; Kim, Y.M.; Rhee, H.S.; Lee, M.W.; Park, J.M. Bioethanol production from mannitol by a newly isolated bacterium, Enterobacter sp. JMP3. Bioresour. Technol. 2013, 135, 199-206. [CrossRef] [PubMed]

6. Balat, M. Production of bioethanol from lignocellulosic materials via the biochemical pathway: A review. Energy Convers. Manag. 2011, 52, 858-875. [CrossRef]

7. Küüt, A.; Ritslaid, K.; Olt, J. Study of potential uses for farmstead ethanol as motor fuel. Agron. Res. 2011, 9, 125-134.

8. Mahalaxmi, S.; Williford, C. Biochemical conversion of biomass to fuels. In Handbook of Climate Change Mitigation; Springer: Berlin, Germany, 2012; pp. 965-999.

9. Sebayang, A.H.; Masjuki, H.H.; Ong, H.C.; Dharma, S.; Silitonga, A.S.; Mahlia, T.M.I.; Aditiya, H.B. A perspective on bioethanol production from biomass as alternative fuel for spark ignition engine. RSC Adv. 2016, 6, 14964-14992. [CrossRef]

10. Yangcheng, H.; Jiang, H.; Blanco, M.; Jane, J.-L. Characterization of normal and waxy corn starch for bioethanol production. J. Agric. Food Chem. 2013, 61, 379-386. [CrossRef] [PubMed]

11. Brunschwig, C.; Moussavou, W.; Blin, J. Use of bioethanol for biodiesel production. Prog. Energy Combust. Sci. 2012, 38, 283-301. [CrossRef]

12. Ahmed, I.N.; Nguyen, P.L.T.; Huynh, L.H.; Ismadji, S.; Ju, Y.-H. Bioethanol production from pretreated Melaleuca leucadendron shedding bark-Simultaneous saccharification and fermentation at high solid loading. Bioresour. Technol. 2013, 136, 213-221. [CrossRef] [PubMed]

13. Yu, C.-Y.; Jiang, B.-H.; Duan, K.-J. Production of bioethanol from carrot pomace using the thermotolerant yeast kluyveromyces marxianus. Energies 2013, 6, 1794-1801. [CrossRef]

14. Moshi, A.P.; Hosea, K.M.M.; Elisante, E.; Mamo, G.; Mattiasson, B. High temperature simultaneous saccharification and fermentation of starch from inedible wild cassava (Manihot glaziovii) to bioethanol using caloramator boliviensis. Bioresour. Technol. 2015, 180, 128-136. [CrossRef] [PubMed]

15. Moshi, A.P.; Crespo, C.F.; Badshah, M.; Hosea, K.M.M.; Mshandete, A.M.; Mattiasson, B. High bioethanol titre from Manihot glaziovii through fed-batch simultaneous saccharification and fermentation in automatic gas potential test system. Bioresour. Technol. 2014, 156, 348-356. [CrossRef] [PubMed]

16. Li, P.; Zhu, M. A consolidated bio-processing of ethanol from cassava pulp accompanied by hydrogen production. Bioresour. Technol. 2011, 102, 10471-10479. [CrossRef] [PubMed]

17. Zhang, W.; Lin, Y.; Zhang, Q.; Wang, X.; Wu, D.; Kong, H. Optimisation of simultaneous saccharification and fermentation of wheat straw for ethanol production. Fuel 2013, 112, 331-337. [CrossRef]

18. Dharma, S.; Masjuki, H.H.; Ong, H.C.; Sebayang, A.H.; Silitonga, A.S.; Kusumo, F.; Mahlia, T.M.I. Optimization of biodiesel production process for mixed Jatropha curcas-Ceiba pentandra biodiesel using response surface methodology. Energy Convers. Manag. 2016, 115, 178-190. [CrossRef]

19. Ali, O.; Mamat, R.; Najafi, G.; Yusaf, T.; Safieddin Ardebili, S. Optimization of biodiesel-diesel blended fuel properties and engine performance with ether additive using statistical analysis and response surface methods. Energies 2015, 8, 14136-14150. [CrossRef]

20. Cheng, Y.; Wang, J.; Jönsson, P.G.; Zhao, Z. Improvement and optimization of the growth quality of upright $\mathrm{ZnO}$ rod arrays by the response surface methodology. Appl. Surf. Sci. 2015, 351, 451-459. [CrossRef]

21. Moshi, A.P.; Crespo, C.F.; Badshah, M.; Hosea, K.M.M.; Mshandete, A.M.; Elisante, E.; Mattiasson, B. Characterisation and evaluation of a novel feedstock, Manihot glaziovii, Muell. Arg, for production of bioenergy carriers: Bioethanol and biogas. Bioresour. Technol. 2014, 172, 58-67. [CrossRef] [PubMed] 
22. Gumienna, M.; Szwengiel, A.; Lasik, M.; Szambelan, K.; Majchrzycki, D.; Adamczyk, J.; Nowak, J.; Czarnecki, Z. Effect of corn grain variety on the bioethanol production efficiency. Fuel 2016, 164, 386-392. [CrossRef]

23. Meinita, M.D.N.; Marhaeni, B.; Winanto, T.; Setyaningsih, D.; Hong, Y.-K. Catalytic efficiency of sulfuric and hydrochloric acids for the hydrolysis of Gelidium latifolium (Gelidiales, Rhodophyta) in bioethanol production. J. Ind. Eng. Chem. 2015, 27, 108-114. [CrossRef]

24. Tasić, M.B.; Konstantinović, B.V.; Lazić, M.L.; Veljković, V.B. The acid hydrolysis of potato tuber mash in bioethanol production. Biochem. Eng. J. 2009, 43, 208-211. [CrossRef]

25. Naguleswaran, S.; Li, J.; Vasanthan, T.; Bressler, D.; Hoover, R. Amylolysis of large and small granules of native triticale, wheat and corn starches using a mixture of $\alpha$-amylase and glucoamylase. Carbohydr. Polym. 2012, 88, 864-874. [CrossRef]

26. Masum, B.M.; Masjuki, H.H.; Kalam, M.A.; Rizwanul Fattah, I.M.; Palash, S.M.; Abedin, M.J. Effect of ethanol-gasoline blend on $\mathrm{NO}_{x}$ emission in SI engine. Renew. Sustain. Energy Rev. 2013, 24, 209-222. [CrossRef]

27. Miller, G.L. Use of dinitrosalicylic acid reagent for determination of reducing sugar. Anal. Chem. 1959, 31, 426-428. [CrossRef]

28. Dodić, J.M.; Vučurović, D.G.; Dodić, S.N.; Grahovac, J.A.; Popov, S.D.; Nedeljković, N.M. Kinetic modelling of batch ethanol production from sugar beet raw juice. Appl. Energy 2012, 99, 192-197. [CrossRef]

29. Moshi, A.P.; Temu, S.G.; Nges, I.A.; Malmo, G.; Hosea, K.M.M.; Elisante, E.; Mattiasson, B. Combined production of bioethanol and biogas from peels of wild cassava Manihot glaziovii. Chem. Eng. J. 2015, 279, 297-306. [CrossRef]

30. Sivamani, S.; Baskar, R. Optimization of bioethanol production from cassava peel using statistical experimental design. Environ. Prog. Sustain. Energy 2015, 34, 567-574. [CrossRef]

31. Yadira, P.-S.B.; Sergio, S.-T.; Fernando, S.E.L.; Sebastian, P.J.; Eapen, D. Bioethanol production from coffee mucilage. Energy Procedia 2014, 57, 950-956. [CrossRef]

(c) 2017 by the authors; licensee MDPI, Basel, Switzerland. This article is an open access article distributed under the terms and conditions of the Creative Commons Attribution (CC-BY) license (http://creativecommons.org/licenses/by/4.0/). 